\title{
Legal Examination of Corruption on Social Assistance in State Officers in State during Emergencies / National Disasters
}

\author{
Eva Yunita Siregar ${ }^{1}$, Sriono $^{2}$, Muhammad Yusuf Siregar ${ }^{3}$ \\ ${ }_{1,2,3}$ Law Study Program, Faculty of Law, Labuhanbatu University, Indonesia \\ Sriono.mkn@gmail.com
}

\begin{abstract}
Abuse often occurs among politicians and state officials or officials who have authority or power over governance. Such misuse is like bribery for Social Funding, namely by receiving a certain amount of money to enrich oneself and fulfill all needs as suspected by the Corruption Eradication Commission to the Minister of Social Affairs of the Republic of Indonesia in 2020. The acts of corruption are committed when the state is in an emergency (national disaster) will certainly have an impact on the types of lawsuits. Provisions regarding national disasters as determined by the State. This study aims to analyze from a legal point of view criminal acts in the form of corruption in covid-19 social assistance funds. The method used in this research is normative juridical. Juridical normative is a method using secondary data in the form of library materials and statutory approaches (Statute Approach) and an approach to cases related to the author's title (Case Approach). The results showed that an act of corruption committed by a government official could be punished by imprisonment, but if the act of corruption was committed in certain circumstances (emergency/disaster) then the perpetrator could be sentenced to death.
\end{abstract}

Keywords

abuse; social assistance; corruption; punishment

\section{Introduction}

At the end of 2019, to be precise in December, the world was shocked by an incident that was suspected of a pneumonia case whose etiology was unknown, the case originating from the city of Wuhan, China. China identified pneumonia on January 7, 2020 as a new type of coronavirus.(Adam, Noviyanto, \& Prasetyo, 2021). Indonesia is being shaken by the coronavirus-19 outbreak which has been confirmed to be contagious and has resulted in an increase in deaths in Indonesia. To prevent the occurrence of rapid transmission for Indonesian citizens, the government makes rules by staying at home, keeping your distance and not recommending crowds or crowds. With these rules, there are many impacts on the community, especially in areas where Covid-19 has been confirmed with limited detection. Activities and neglected breadwinners to meet the daily needs of the family.

Since the first positive cases of Covid-19 were announced in Indonesia, the Provincial Government of DKI Jakarta has taken steps to prevent the spread of Covid-19 in the City of Jakarta (Hanafi, Syafii, Ramadhan, \& Prayoga, 2020). The more rapid development regarding the spread of the virus to areas the government is implementing Large-Scale Social Restrictions (PSBB) in a number of Jakarta areas with it being officially enforced. With the enactment of social restrictions by the government, it will have many impacts on the economic sector. Many workers will be subject to termination of employment (PHK) by the company. (Yamali \& Putri, 2020). This pandemic caused a significant economic decline and increased the number of unemployed people in Indonesia 
because to avoid crowds in order to prevent the spread of Covid-19, many workers lost their jobs. The government did not remain silent in facing this sad condition. Handling the impact of the economic downturn is immediately carried out by the government, such as providing social assistance to the community by issuing financial policies as a quick and extraordinary step in dealing with Covid-19. The Ministry of Home Affairs issued a Regulation of the Minister of Home Affairs (Permendagri) Number 20 of 2020 concerning the handling of covid-19 (Sudaryanto, 2020). In the regulation of the Minister of Home Affairs,Adam et al., 2021). The government provides many types of social assistance so that this assistance can ease the burden on people in distress. Many types of social assistance are provided by the government to ease the burdens on the community, namely, direct cash assistance with an amount of Rp. 600,000.00 per month and obtained for 4 consecutive months, basic foodstuffs. with many types given such as salt, sugar, eggs, edible oil, and other food needs, rice, and others.

Along with the expansion of the social assistance program, the budget provided by the government will also increase and will open the door for corruptors who want to increase their profits and enrich themselves above the screams and cries of the people who are experiencing difficulties. Local government and this will create a lot of unrest because this policy will create many problems both in terms of fraud and misuse of budget funds. Lately, cyberspace is busy discussing the application of the death penalty for criminal acts of corruption committed during the Covid 19 pandemic. as in the legal problems experienced by the non-active Indonesian Minister of Social Affairs Julian Peter Batubara. He received a total of Rp. 17 billion from the two social assistance packages for handling covid 19. The money was used for personal needs. The provision of social assistance for handling covid 19 in the form of basic food packages at the Ministry of Social Affairs in 2020 has a value of around Rp. 59 Trillion with a total of 272 contracts and executed in two periods. Where the fee for each social assistance package is Rp. 10 thousand per basic food package of Rp. 30 thousand per social assistance package. Of course, the actions committed by the Minister of Social Affairs of the Republic of Indonesia are very cruel and do not have a sense of humanity towards others. Food packages which are basically intended for people affected by Covid 19 are instead being misused and used for their own personal gain and needs The provision of social assistance for handling covid 19 in the form of basic food packages at the Ministry of Social Affairs in 2020 has a value of around Rp. 59 Trillion with a total of 272 contracts and executed in two periods. Where the fee for each social assistance package is Rp. 10 thousand per basic food package of Rp. 30 thousand per social assistance package. Of course, the actions committed by the Minister of Social Affairs of the Republic of Indonesia are very cruel and do not have a sense of humanity towards others. (Setiyawan, 2021)

Indonesia is a country where many people take steps to enrich themselves for the benefit of themselves or a corporation and abuse their authority for their own happiness which we usually refer to as corruption. Corruption is an act that violates statutory regulations, whoever commits this action will be punished in accordance with law No. 20 of 2001 in conjunction with law No. 31 of 1999 concerning the eradication of criminal acts of corruption. The death penalty for corruption during the Covid 19 pandemic itself has been regulated in Article 2 paragraph (2) of Law Number 31 of 1999 as amended by Law Number 20 of 2001 concerning Eradication of Corruption Crimes. As for the legal case experienced by Julian Peter Batubara, it fulfills the elements contained in this article. As the decision has been issued by President Joko Widodo through Presidential Decree No.11 of 2020 concerning the Determination of the 2019 Corona Virus Disease Public Health Emergency (Covid 19). And Presidential Decree Number 12 of 2020 concerning the 
Determination of Non-Natural Disasters for the Spread of Corona Virus Disease 2019 (Covid 19).

The Organization for economic cooperation and development (OECD) defines corruption as "abuse in a public or private position or position in order to gain its own benefits, either directly or indirectly". The government pays more attention to and supervises corruption committed by civil servants or state officials who commit acts of corruption by extorting the public and ordering people to pay a certain amount of money to get their rights that have been given by the government. position is regulated in article 12 letter e of the law on corruption, which reads "Civil servants or state administrators with the intention of unlawfully benefiting themselves or others.

Corruption is a specific criminal act which is regulated outside of the Criminal Code, Corruption is a criminal act which involves bribery manipulation and acts against the law that are detrimental or can harm the country's finances or the country's economy, detrimental to the welfare or interests of the people / general. Acts that are detrimental to the country's finances or economy are corruption in the material field, while corruption in the political field can be realized in the form of manipulating the vote by bribery, coercion intimidation and or interference that affects the freedom of choice to vote-commercialize in the legislative body or in administrative decisions in the field of implementation government. (Zulyadi, 2020)

According to Andi Hamzah, the criminal act of corruption is a polemic phenomenon of crime that undermines and hinders the implementation of development, therefore in the prevention and eradication of corruption must be prioritized. We encounter many perpetrators of criminal acts in modern society, so that corruption in our country is rapidly developing both in quality and quantity. Even though the prevention of criminal acts of corruption is prioritized, it is recognized that corruption is a type of case that is difficult to handle and eradicate.

Acts against the law and Abuse of authority in criminal acts of corruption are regulated in Article 2 and Article 3 of Law Number 31 of 1999 as amended to Law Number 20 of 2001 concerning Eradication of Corruption (UUPTPK). There is a fundamental difference between the two acts, even though the two acts are elements that determine whether or not an action can be declared a criminal act, furthermore the two acts are also important to determine whether someone can be blamed for corruption or not. (Purba and syahrin, 2019)

Zhajawri said that so far, corruption has been tolerated more by various parties than to eradicate it, even though the criminal act of corruption is a type of crime that can touch various interests regarding human rights, State ideology, economy, State finances, national morals and so on, which is evil behavior tends to be difficult to overcome.

\section{Research Methods}

Peter Mahmud Marzuki argues that legal research is a process to find legal rules, legal principles, and legal doctrines in order to answer legal issues at hand. This is in accordance with the character of the perspective of law science. Research methods used in this research is normative juridical or also known as doctrinal law research, namely legal research which is carried out by examining secondary data in the form of reading material or library, journals, theses and several relevant sites for use. The author collects data which is the source of research which is data related to the author's title. The approach used in this research is a statutory approach (statute opproach), namely by observing, analyzing and analyzing statutory regulations related to article titles. 
The data source used is secondary data or legal material as the main data, which consists of primary legal materials including Law No. 31 of 1999 amendments to Law No. 20 of 2001 concerning the Eradication of Corruption, Criminal Code and Law No. 28 of 1999 concerning the Administration of a State Clean from Corruption, Collusion and Nepotism. Secondary legal materials are legal facts, expert opinion, doctrine, legal principles. Thesis materials include a large Indonesian dictionary (KBBI) and a dictionary law (Black's law dictionary).

\section{Results and Discussion}

\subsection{Misuse of Social Assistance during the Covid Pandemic - 19}

Abuse in KBBI has the meaning, namely, the process, method, act of abusing; diversion. The abuse that is carried out is solely for his own benefit to get something he wants. Abuse of authority can only be done by someone who has the authority stipulated in writing by a formal regulation.(Law of the Republic of Indonesia Number 31 of 1999 concerning Eradication of Corruption)

Corruption or rasuah (Latin: corruptio) is the act of public officials, both politicians and civil servants, as well as other parties involved in the act who unfairly and illegally commit an act that deviates from their authority by abusing public trust to obtain unilateral advantage. (Salle, 2019) "Financial manipulations and deliction injurious to the economy are often labeled corrupt". Furthermore, he explained that "the term is often applied also to misjudgements be officials in the public economies" he also said: "disguised payment in the form of gifts, legal fees, employment, favors to relatives, social influence, or any relationship sacrafices the public and welfare, with or without the implied payment of money, is usually considered corrupt. He also described other forms of corruption, which are termed political corruption, namely: "electoral corruption includes purchase of vote whit money, promises of office or special favors, coercion, intimidation, and interference with administrative of judicial decisions or governmental appointments.

An act of abusing and abusing social assistance is absolutely despicable. Ideally, a rule of law and uphold the values that live in society, social assistance should be used according to the designation stipulated in Indonesian regulations. Mistakes in the management of state finances cause their use to be misdirected and cause state losses. errors occur because the perpetrators deliberately or negligently manage state finances. the relation of criminal law to the problem of state losses because the act is carried out to enrich oneself, other people, corporations that cause losses to state finances and even the state economy (Yusrizal, 2020).

In the case of abuse of power, there are characteristics that lead to abuse of authority.

1. Going Beyond Authority

The granting of authority to an agency or state administrator by always expressing their aims and objectives for their own wishes regardless of the irrelevance of said aims and objectives with the authority given to that state agency or administrator can be said to have committed abuse of authority.

2. Mixing Authority

Category of action confuses authority exercised by government agencies and / or officials as stated in Article 18 paragraph (2), namely if the decisions and / or actions taken are outside the scope of the field or material of the authority given; and / or contrary to the purpose of the authority given. 
3. Acting Arbitrary.

Government Agencies and / or Officials are categorized as acting arbitrarily as referred to in Article 17 paragraph (2) letter c of Law Number 30 of 2014 concerning Government Administration if the Decision and / or Actions are taken: a. without the basis of authority; and / or b. contradicts the Court Decision which is legally binding. An official who acts without the basis of authority is called acting arbitrarily. Likewise, if an official issues a decision that is contrary to a decision which has permanent legal force, then the official is deemed to have acted arbitrarily.(Rini, 2016).

Law No. 28 of 1999 concerning the administration of a country that is clean and free from corruption, collusion and nepotism in;

Article 3:

a) The Principle of Legal Certainty

Namely principles that are based on statutory regulations,

b) The principle of orderly state administration

Namely the principles which become the basis of order, harmony and balance in the control of state administrators.

c) Principle of Public Interest

Namely the principle that prioritizes the general will in an aspirational, accommodating and selective way.

d) The principle of openness

Namely the principle of transparency of the rights of the people to obtain true, honest, and non-discriminatory information regarding the administration of the State while still paying attention to the protection of personal human rights, state secrets.

e) The principle of proportionality

Namely the principle that prioritizes the balance between the rights and obligations of state administrators.

f) The principle of professionalism

Namely the principle that prioritizes expertise based on a code of ethics and the provisions of the prevailing laws and regulations.

g) The principle of accountability.

Namely the principle which determines that every activity and the final results of the activities of the State administrators must be accountable to the public or the people as the holder of the supreme sovereignty of the State in accordance with the provisions of the legislation in force.(Law of the Republic of Indonesia Number 28 of 1999 concerning the Implementation of a State that is Clean and Free from Corruption, Collusion, and Nepotism).

\subsection{Impact of Misuse of Social Assistance Funds during the Covid-19 Pandemic \\ a. Impact on the Country's Economy}

The impact of covid-19 that can be felt by all groups of people is in the economic sector. Barriers to doing outdoor activities are one of the factors that make Indonesia's economy decline. The government budget has also been readjusted for handling Covid 19 . Poor bureaucracy and supervision resulted in opportunities for individuals to take advantage of disaster funds or social assistance funds.(Dhimas, 2021)

During the pandemic disease (covid-19) that was happening in Indonesia, it had many impacts both in terms of economy and social life. Economy is closely related to everyday life, the economy is also a very important factor in aspects of life such as eating, drinking and doing activities that really require a stable economy. With the occurrence of a pandemic disease in our country, the government must issue a policy to to help the people's 
economy because good economic growth in a country can also increase a national development in the country.

In the concept of a welfare state, the state has the right to interfere in all aspects of the life of its citizens, including in the economic sector. Apart from that, economic growth is also a factor that supports national development in a country. Good economic growth will be able to increase national development.(Syarip, 2020) The impact on the economic sector during the Covid-19 pandemic in Indonesia, among others (Yamali \& Putri, 2020) :

1. The occurrence of layoffs on a large scale. The results of the data obtained are $\geq 1.5$ million workers at home and affected by layoffs, of which $90 \%$ of workers were at home and $10 \%$ of workers were laid off.

2. There was a decrease in the Indonesian Manufacturing PMI to reach 45.3\% in March 2020.

3. There was a decline in imports of $3.7 \%$ in the first quarter.

4. Inflation has reached $2.96 \%$ year-on-year (yoy) which has been contributed from the price of gold and food commodities in March 2020.

5. The occurrence of flight cancellations which resulted in decreased revenue in the sector. The loss that was felt reached Rp. 207 billion. There were 12,703 flight cancellations at 15 airports in January-March 2020.

6. At 6 thousand hotels there has been a decline in occupancy by up to $50 \%$. This can result in loss of tourism foreign exchange (Hanoatubun, 2020).

The real form that we have seen in our environment is the occurrence of significant layoffs and many companies are threatened with bankruptcy, if the situation lasts longer, the number of unemployed will increase and have an impact on other aspects such as restaurant businesses, cafes, MSME actors, and other ventures that can involve large numbers of people.

\section{b. Impact on Perpetrators of Social Assistance Abuse}

Corruption cases are familiar to our ears, Indonesia is one of the countries that has many cases of corruption. This deviant and unlawful act occurred again during the Covid19 pandemic, which shows that the punishments that have been given to other corruptors have not had a deterrent effect on the perpetrators of criminal acts of corruption, therefore things seem to be repeated. The threat of punishment against the perpetrators of criminal acts of corruption has been regulated in Law No. 20 of 2001 on amendments to Law No. 31 of 1999 concerning the eradication of criminal acts of corruption.

The perpetrator of a crime must be subject to a legal consequence. The legal consequences generally take the form of a crime. From the point of view of the convict's loss, the punishment may involve the following:

a. Soul of the perpetrator: death penalty;

b. Bodies of perpetrators: repeated whipping with rattan, cutting of body parts (for example, hand teak), "stamped bara" (brand brand) and so on;

c. Independence of the perpetrator: imprisonment, imprisonment, imprisonment, exile (vernbannig), exile (deportatie), expulsion, eviction, detention and so on;

d. Honor of perpetrators: revocation of certain rights, revocation of a driving license, announcement of a judge's decision, warning and so on;

e. Assets / assets: criminal fines, confiscation of goods (certain), paying for goods that are not / have not been confiscated according to interpretation and so on. (Leasa, 2021).

The death penalty is one of the criminal institutions in the penitentiary realm of law, especially in Indonesia. The death penalty is stated in Article 10 of the Criminal Code. The criminal institution referred to here is a legal institution that is mentioned in positive law which is directly related to convictions carried out by judges.(Bustamam \& Share, 2020) 
1. The case that is currently happening in Indonesia is regarding the case of social minister Julian Peter Coal and his four other suspects, namely the Commitment Making Officer (PPK) at the Ministry of Social Affairs, Ardian IM and Harry Sidabuke as private parties and Matheus Joko Santoso and Adi Wahyono. Actions taken by the Minister of Social Affairs and his colleagues are regulated in Law No. 31/1999 jo Law No. 20/2001 Article 2 concerning the eradication of criminal acts of corruption.

2. Every person who unlawfully commits an act of enrichment of himself or another person or a corporation which can cause losses to the state's finances or the country's economy, shall be punished with life imprisonment or imprisonment for a minimum of 4 (four) years and a maximum of 20 (twenty). years and a fine of at least Rp. $200,000,000.00$ (two hundred million rupiah) and a maximum of Rp. 1,000,000,000.00 (one billion rupiah).

3. In the event that the criminal act of corruption as referred to in paragraph (1) is committed under certain circumstances, the death penalty may be imposed.

Article 2 paragraph (2) states that the death penalty can be imposed on the perpetrator of a criminal act of corruption if it is carried out in certain circumstances, so capital punishment is a penal weighting if it fulfills the requirements for weighting that is in certain circumstances. In the elucidation of Article 2 paragraph (2), namely what is meant by "certain conditions" in this provision is intended as a deterrent to the perpetrator of the criminal act of corruption if the criminal act is committed when the state is in a state of danger in accordance with the applicable law, at the time of disaster. in the national realm, as a repetition of the criminal act of corruption, or when the country is in a state of economic and monetary crisis.(Leasa, 2021). Therefore, the misuse of social assistance funds during this pandemic can be categorized as a certain condition which is a non-natural disaster that affects the country's economy in which the perpetrator of the criminal act of corruption is subject to capital punishment if he commits an act detrimental to the country's economy during the pandemic.

The establishment of Perppu No.1 of 2020 actually weakens law enforcement on the Corruption Act and its amendments. In which the Perppu contains Financial Policies and Financial System Stability for Handling the Covid 19 Pandemic in article 27 paragraph 1 of Perppu 1/2020 which must be considered in the article, it reads: "Costs that have been incurred by the Government and / or the KSSK member institutions in the context of implementing the state revenue policy including policies in the field of taxation, state expenditure policies including policies in the regional finance sector, financing policies, financial system stability policies, and the national economic recovery program, are part of the of economic costs to save the economy from the crisis and not a loss to the state."

And Article 27 Paragraph (2) reads: "Members of the KSSK, Secretary of the KSSK, members of the KSSK secretariat, and officials or employees of the Ministry of Finance, Bank Indonesia, the Financial Services Authority, and the Deposit Insurance Corporation, and other officials related to the implementation of the Substitute Government Regulation. This Law, cannot be prosecuted either civil or criminal if in carrying out tasks based on good faith and in accordance with the provisions of laws and regulations ". (Mufida, 2020)

The perspective of human rights (HAM) is the basis for the contra in imposing the death penalty for the perpetrators of corruption. The legal basis for this opinion is contained in article 3 of the Universal Declaration of Human Rights of 1948 which states that: "Everyone has the right to life, liberty and safety as an individual". Article 28A of the 1945 Constitution of the Republic of Indonesia states that: "The right to live and defend life and life". Article 28I of the 1945 Constitution of the Republic of Indonesia states that: Paragraph (1) "The right not to be prosecuted on a retroactive basis of law". Paragraph (2) 
"The right to be free from discriminatory treatment on any basis and the right to receive protection from such discriminatory treatment".(Dhimas, 2021).

The polemic in the imposition of capital punishment for perpetrators of criminal acts of corruption during the pandemic is very confusing and raises pros and cons of regulations made by the government. the death penalty should be applied to perpetrators of criminal acts of corruption, whether in a pandemic or not. Although the actions of the corruptors are considered an error that must be accounted for legally, the fact that the death penalty has never been sentenced makes Indonesia a new commodity for perpetrators of corruption. Until now, judges have never sentenced a death penalty for violators of Article 2 of the Anti-Corruption Law. Thus, now is the right time for law enforcers, especially judges, to operationalize capital punishment against corruptors during the Covid-19 pandemic.(Muqorobin \& Arief, 2020)

\section{Conclusion}

Corruption is an act that violates state regulations that cannot be eradicated until now. There are many laws and regulations that clearly and clearly regulate the causes and consequences of criminal acts of corruption in order to deter the perpetrators of corruption. And not repeating mistakes. The factors of the occurrence of criminal acts of corruption are usually supported by the existence of opportunities or opportunities, urgent circumstances, the presence of greed within and weak supervision by state officials.

During the pandemic, the disease that hit Indonesia resulted in a decline in the economy and many Indonesians experienced layoffs the government makes a policy by issuing a budget for social assistance funds for people affected by pandemic disease. With the large amount of budget issued by the government, it is an opportunity for corrupt actors who wish to accumulate wealth instantly and satisfy themselves. Corruption has been regulated in Law No. 20 of 2001 in conjunction with Law No. 31 of 1999 on Corruption Eradication. Legal arrangements for the prevention of social assistance corruption are also contained in the KPK Circular Letter Number 11 of 2020 concerning the Use of Integrated Social Welfare Data (DTKS) and Non-DTKS data, while still referring to the existing laws and regulations on it.

Article 2 paragraph (2) Law No. 31 of 1999 jo Law No. 20 of 2001 "In the event that the criminal act of corruption as referred to in paragraph (1) is committed under certain circumstances, the death penalty may be imposed. " the elucidation of Article 2 paragraph (2) states that: "What is meant by" certain conditions "is if the perpetrator of the criminal act of corruption is committed when the state is in a state of danger in accordance with the applicable law, at the time of a national natural disaster, as a repetition of the act. corruption, or when the country is in a state of economic and monetary crisis". In the element of "certain circumstances" here our country has been designated as a country experiencing non-natural disasters that have resulted in an economic crisis related to Presidential Decree No. 12 of 2020 concerning the Determination of Non-Natural Disasters for the Spread of Corona Virus Disease 2019 (Covid 19). However, until now the implementation of the regulation from Article 2 has not been seen in the case that is currently being discussed in the community regarding the bribery of social assistance funds from the social minister, Julian Peter Coal and the four other suspect colleagues. If seen from this case, the social minister has fulfilled the elements of a certain situation described in article 2 paragraph (2) of the Corruption Eradication Law. 


\section{References}

Adam, S., Noviyanto, I., \& Prasetyo, A. (2021). The establishment of public opinion through social 18. Syntax Admiration, 2(1), 145-161.

Bustamam, A., \& Bagi, P. M. (2020). Pidana mati bagi koruptor dana bencana non alam. Legitimasi, 9(12), 260-280.

Dhimas, W. dan S. (2021). Solusi Pemberantasan Korupsi Di Indonesia Dalam Perspektif Histori Dan Yuridis. Jurnal Education and Development Institut Pendidikan Tapanuli Selatan, 9(1), 68-71.

Leasa, E. Z. (2021). Eksistensi Ancaman Pidana Mati Dalam Tindak Pidana Korupsi Pada Masa Pandemik Covid-19. Jurnal Belo, 6(c), 73-88.

Mufida, A. (2020). Polemik Pemberian Hukuman Mati Pelaku Korupsi di Tengah Pandemi Covid 19. Buletin Hukum Dan Keadilan, 4(1), 223-230.

Muqorobin, M. K., \& Arief, B. N. (2020). Kebijakan Formulasi Pidana Mati dalam Undang-Undang Pemberantasan Tindak Pidana Korupsi pada Masa Pandemi Corona Virus Disease 2019 ( COVID-19 ) Berdasarkan Perspektif Pembaharuan Hukum Pidana. Jurnal Pembangunan Hukum Indonesia, 2(3), 387-398.

Purba, G and Syahrin, A. (2019). Demand against Law and Using Authority in Corruption Criminal Action. Budapest International Research and Critics Institute-Journal (BIRCI-Journal). P.194-206.

Rini, N. S. (2016). Penyalahgunaan Kewenangan Administrasi Dalam UU TIPIKOR. Jurnal Penelitian Hukum, 16(740), 231-244.

Salle, A. (2019). Penyalahgunaan Bantuan Sosial Di Lingkungan Pemerintah Daerah: Fakta Nyata Dari Laporan Hasil Pemeriksaan Keuangan. Jurnal Kajian Ekonomi \& Keuangan Daerah, 4(April), 1-14.

Setiyawan, D. (2021). Analisis Yuridis Terhadap Hukuman Mati Bagi Koruptor Pada Masa PandemI. Jurnal As-Said.LP2M.Institut Agama Islam Abdullah Said Batam, 1(1), 59.

Syarip, A. dan A. M. (2020). Dampak Covid-19 Terhadap Perekonomian Masyarakat Dan Pembangunan Desa. Jurnal Penelitian Hukum Ekonomi Islam, 5(1), 10-20.

Undang-Undang Republik Indonesia Nomor 28 Tahun 1999 Tentang Penyelenggaraan Negara Yang Bersih Dan Bebas Dari Korupsi,Kolusi, Dan Nepotisme.

Undang-Undang Republik Indonesia Nomor 31 Tahun 1999 Tentang Pemberantasan Tindak Pidana Korupsi.

Yamali, F. R., \& Putri, R. N. (2020). Dampak Covid-19 Terhadap Ekonomi Indonesia. Journal of Ekonomics and Business, 4(September), 384-388. https://doi.org/10.33087/ekonomis.v4i2.179

Yusrizal. (2020). Tanggung Jawab Negara Terhadap Pengawasan Bantuan Sosial Selama Pandemi Covid-19. Suloh Jurnal Program Studi Magister Hukum, 19(Oktober), 2136

Zulyadi, R. (2020). Judge's Role in Court to Eradicate Corruption According to Law Number 20 in 2001 (Study of Decision 16/PID.SUS.K/2011/PN.MDN). Budapest International Research and Critics Institute-Journal (BIRCI-Journal). P. 1280-1288 